\title{
A nonclassical bHLH-Rbpj transcription factor complex is required for specification of GABAergic neurons independent of Notch signaling
}

\author{
Kei Hori, ${ }^{1}$ Justyna Cholewa-Waclaw, ${ }^{2}$ Yuji Nakada, ${ }^{1}$ Stacey M. Glasgow, ${ }^{1}$ Toshihiko Masui, ${ }^{3}$ \\ R. Michael Henke, ${ }^{1}$ Hendrik Wildner, ${ }^{2}$ Benedetta Martarelli, ${ }^{2}$ Thomas M. Beres, ${ }^{3}$ \\ Jonathan A. Epstein, ${ }^{4}$ Mark A. Magnuson, ${ }^{5,6}$ Raymond J. MacDonald, ${ }^{3}$ Carmen Birchmeier, ${ }^{2}$ and \\ Jane E. Johnson ${ }^{1,7}$ \\ ${ }^{1}$ Department of Neuroscience, University of Texas Southwestern Medical Center, Dallas, Texas 75390, USA; \\ 2Max-Delbrück-Centrum for Molecular Medicine, 13125 Berlin-Buch, Germany; ${ }^{3}$ Department of Molecular Biology, \\ University of Texas Southwestern Medical Center, Dallas, Texas 75390, USA; ${ }^{4}$ Department of Cell and Developmental \\ Biology, University of Pennsylvania, Philadelphia, Pennsylvania 19104, USA; ${ }^{5}$ Department of Molecular Physiology and \\ Biophysics, Vanderbilt University School of Medicine, Nashville, Tennessee 37232, USA; ${ }^{6}$ Vanderbilt Center for Stem Cell \\ Biology, Vanderbilt University School of Medicine, Nashville, Tennessee 37232, USA
}

Neural networks are balanced by inhibitory and excitatory neuronal activity. The formation of these networks is initially generated through neuronal subtype specification controlled by transcription factors. The basic helix-loop-helix (bHLH) transcription factor Ptf1a is essential for the generation of GABAergic inhibitory neurons in the dorsal spinal cord, cerebellum, and retina. The transcription factor Rbpj is a transducer of the Notch signaling pathway that functions to maintain neural progenitor cells. Here we demonstrate Ptf1a and Rbpj interact in a complex that is required in vivo for specification of the GABAergic neurons, a function that cannot be substituted by the classical form of the bHLH heterodimer with E-protein or Notch signaling through Rbpj. We show that a mutant form of Ptf1a without the ability to bind Rbpi, while retaining its ability to interact with E-protein, is incapable of inducing GABAergic (Pax2)- and suppressing glutamatergic (Tlx3)-expressing cells in the chick and mouse neural tube. Moreover, we use an Rbpj conditional mutation to demonstrate that Rbpj function is essential for GABAergic specification, and that this function is independent of the Notch signaling pathway. Together, these findings demonstrate the requirement for a Ptf1a-Rbpj complex in controlling the balanced formation of inhibitory and excitatory neurons in the developing spinal cord, and point to a novel Notch-independent function for Rbpj in nervous system development.

[Keywords: Ptfla; Notch; cerebellum; dorsal spinal cord; neuronal specification; bHLH transcription factor]

Supplemental material is available at http://www.genesdev.org.

Received May 23, 2007; revised version accepted November 14, 2007.

Normal nervous system function requires the correct balance of inhibitory and excitatory neurons. Alterations in this balance are thought to underlie diverse neurological disorders from epilepsy to autism to hyperalgesia. Although a handful of transcription factors have been shown to initiate the formation of these two major classes of neurons in multiple CNS regions, we have an incomplete understanding of the mechanisms that regulate this balance. In the cerebellum, dorsal spinal cord,

${ }^{7}$ Corresponding author.

E-MAIL jane.johnson@utsouthwestern.edu; FAX (214) 648-1801.

Article is online at http://www.genesdev.org/cgi/doi/10.1101/gad.1628008. and retina, the basic helix-loop-helix (bHLH) transcription factor Ptfla (p48) plays a central role in the generation of inhibitory GABAergic neurons while suppressing the generation of excitatory glutamatergic neurons (Glasgow et al. 2005; Hoshino et al. 2005; Fujitani et al. 2006; Nakhai et al. 2007; Pascual et al. 2007). Here we demonstrate that Ptf1a utilizes a nonclassical bHLH transcription factor complex for these functions.

Inhibitory and excitatory interneurons in the dorsal horn of the spinal cord require the combined actions of bHLH and homeodomain (HD) transcription factors (Gowan et al. 2001; Gross et al. 2002; Müller et al. 2002; Cheng et al. 2004, 2005; Glasgow et al. 2005; Helms et al. 2005; Mizuguchi et al. 2006; Wildner et al. 2006). Neu- 
rogenesis in this CNS region is characterized by two waves: an early wave (embryonic day 10-11.5 [E10E11.5]) that generates sensory relay and local interneurons that settle in the deep dorsal horn (dI1-dI6), and a late wave (E11.5-E13) that generates interneurons in the superficial laminae $\left(\mathrm{dIL}^{\mathrm{A}}\right.$ and $\mathrm{dIL}^{\mathrm{B}}$ ) (for reviews, see Caspary and Anderson 2003; Helms and Johnson 2003). Specification of the major GABAergic inhibitory interneurons dI4 and dIL ${ }^{\mathrm{A}}$ requires Ptfla (Glasgow et al. 2005) and the HD factors Lbx1 and Pax2 (Cheng et al. 2004, 2005). In contrast, Ptf1a represses the HD factor Tlx3, a factor required for specification of the major glutamatergic excitatory interneurons $\mathrm{dI} 5$ and $\mathrm{dIL}^{\mathrm{B}}$. Another bHLH factor, Ascl1 (previously Mash1), has a more complex role in specifying these neurons. In early stages it is required with the HD factors Gsh1 and Gsh2 for dI5 glutamatergic neurons (Helms et al. 2005; Mizuguchi et al. 2006), but in the late-born dIL populations it is required for Ptfla expression and, thus, for the dIL ${ }^{\mathrm{A}}$ GABAergic neurons (Mizuguchi et al. 2006; Wildner et al. 2006). The central role played by Ptfla in guiding inhibitory versus excitatory neuronal specification makes it an attractive target for studies revealing the molecular mechanisms controlling neuronal network formation.

Insight into the mechanism of Ptfla function has come from studies of transcriptional control of pancreatic digestive enzymes in the adult pancreas (Beres et al. 2006) and the mapping of human mutations in the PTF1A gene (Sellick et al. 2004). The classical form for a class II bHLH factor such as Ptfla is as a heterodimer with E-protein (for review, see Massari and Murre 2000). However, Ptfla was identified as a component of the pancreas transcription factor complex (PTF1) that is required for expression of pancreatic enzymes such as Elastase1 (Cockell et al. 1989; Krapp et al. 1996, 1998). This protein complex includes Ptfla with any one of the Eproteins, Tcfe2a (E12 and E47), Tcf4 (E2.2), or Tcf12 (HEB), and Rbpil, a homolog of Drosophila Suppressor of Hairless (Beres et al. 2006). Human mutations in PTF1A that resulted in cerebellar and pancreatic agenesis (Hoveyda et al. 1999; Sellick et al. 2004) were identified as truncations that left the bHLH domain intact but deleted the Rbpil interaction domain (Beres et al. 2006). Together, these results suggest the trimeric complex with $\mathrm{Rbpjl}$ is required for normal pancreas. However, it is Rbpj (RBP-Jk, CBF1, CSL, Rbpsuh), not Rbpil, that is present in the developing neural tube and cerebellum. In vitro studies have shown Rbpj can also form a complex with Ptfla and E-protein (Beres et al. 2006).

Rbpj is the vertebrate ortholog of the Drosophila gene Suppressor of Hairless, and is a DNA-binding factor essential in transducing Notch signals during neural development. Rbpi binds to its consensus site DNA in regulatory regions of target genes and mediates the transcriptional effects of Notch signaling by associating with the protease-cleaved Notch intracellular domain (NICD) and coactivators such as Maml (Mastermind-like) (for review, see Louvi and Artavanis-Tsakonas 2006). For example, Rbpj binds and activates transcription from the promoter of the Hes1 gene in the presence of activated
Notch, a mechanism for inhibiting neuronal differentiation (Jarriault et al. 1995). In contrast, in the absence of Notch signaling, Rbpj can recruit corepressors such as the LIM-protein KyoT2, or SMRT and N-CoR, components of histone deacetylase corepressor complexes (Kao et al. 1998; Taniguchi et al. 1998). Extensive studies in vertebrates and invertebrates have demonstrated Rpbj functions via Notch signaling in many processes during neural development, including neural progenitor cell maintenance and promoting the generation of astrocytes (Furukawa et al. 2000; Gaiano et al. 2000; Hitoshi et al. 2002).

In this study, we test the requirement for a transcription complex containing both Ptfla and Rbpj in determining the neuronal identity of GABAergic neurons in the dorsal spinal cord. We demonstrate that a mutant, Ptfla ${ }^{\mathrm{W} 298 \mathrm{~A}}$, is capable of forming a heterodimer with the E-protein Tcf12 but is incapable of forming the heterotrimer with the E-protein plus Rbpj. This mutant has no activity in inducing Ptfla-dependent neurons when overexpressed in the chick neural tube, an activity normally detected with wild-type Ptfla (Wildner et al. 2006). Furthermore, in mice with $\mathrm{Ptf1} \mathrm{a}^{\mathrm{W} 298 \mathrm{~A}}$ replacing the wildtype protein, the phenotype in the dorsal neural tube and cerebellum is identical to the Ptf1a null. Conditional knockout of Rbpj in the dorsal neural tube phenocopies the Ptf1 $\mathrm{a}^{\mathrm{W} 298 \mathrm{~A} / \mathrm{W} 298 \mathrm{~A}}$ in specifying dorsal neuronal identity. Thus, we provide in vivo evidence implicating a protein complex of Ptfla with Rbpj as the essential transcription complex for GABAergic neuronal development in multiple regions of the nervous system.

\section{Results}

Ptf1a ${ }^{\text {W298A }}$ efficiently forms a heterodimer with the E-protein Tcf12 but does not interact with Rbpj

PTF1 is a transcription factor complex identified in adult pancreas (Roux et al. 1989; Beres et al. 2006). In pancreas, this complex consists of Ptfla, Rbpil, and any one of the E-proteins such as Tcf12. However, although Ptfla and E-proteins are present in the developing neural tube, Rbpil is not (R.M. Henke, unpubl.). Biochemical studies demonstrated that a PTF1 complex could contain Rbpj in place of Rbpil (Fig. 1A; Beres et al. 2006). Using RT-PCR from isolated Ptfla lineage cells, we show that Rbpj is present with the other PTF1 complex components, including Ptf1a, Tcf12, Tcf4, and Tcfe2a, in E12.5 neural tube (Fig. 1C). To begin to address whether the functional form of Ptfla in the nervous system requires its interaction with Rbpj, we took advantage of a mutant form of Ptfla that disrupts this interaction. Ptf1a $\mathrm{a}^{\mathrm{W} 298 \mathrm{~A}}$ contains a single amino acid substitution of a conserved tryptophan in the $\mathrm{C}$ terminus of the protein, and it fails to function efficiently with Rbpi to activate transcription in reporter assays (Beres et al. 2006). Furthermore, in contrast to the wild-type Ptfla (Fig. 1B, lanes 5-7), Ptfla ${ }^{\text {W298A }}$ does not coimmunoprecipitate Rbpj when these proteins are coexpressed in COS cells (Fig. 1B, 
Figure 1. Ptf1a $\mathrm{a}^{\mathrm{W} 298 \mathrm{~A}}$ mutant protein efficiently forms a heterodimer with an E-protein (Tcf12) but not with Rbpj. (A) The diagram depicts the PTF1 trimer on DNA containing an E-box and T/C-box. When the tryptophan (W) at position 298 in Ptfla is mutated to an alanine (A), there is a loss of the trimer complex, but the dimer with an E-protein can form. ( $B$ ) Immunoprecipitation (IP) of COS cells transfected with Ptfla wild type, Ptf1a ${ }^{\text {W298A }}$ mutant, Rbpj, or Tcf12 alone (lanes 1-4); cells cotransfected with Ptfla wild type or Ptf1a ${ }^{\text {W298A }}$ mutant with Rbpj (lanes 5,8), or Tcf12 (lanes 6,9); or cells tripletransfected (lanes 7,10). All transfected proteins were myc-tagged. The top panel shows cell lysates immunoprecipitated with antiPtfla antibodies and immunoblotted (WB) with anti-myc antibodies. Equal input of proteins in each sample is shown in Western blot with anti-myc antibodies in the bottom panel. (C) RT-PCR from RNA isolated by FACS from E12.5 Ptf1a $\mathrm{Cre}^{\mathrm{H}} / \mathrm{ROSA26YFP}$ E12.5 neural tubes demonstrating coexpression of the PTF1 trimer components in dorsal neural tube. (RT) Reverse transcriptase.

lanes 8-10). Notably, Ptfla $\mathrm{a}^{\mathrm{W} 298 \mathrm{~A}}$ does retain its ability to interact with E-protein (Fig. 1A,B). These results indicate that the single amino acid substitution of alanine for tryptophan at position 298 specifically impairs the association of Ptfla with Rbpj without impairing its ability to heterodimerize with E-protein.

Ptf1a $a^{\text {298A }}$ fails to induce Pax2 (dIL ${ }^{A}$ neurons) and suppress TlX3 (dIL ${ }^{B}$ neurons) in chick neural tube

Ectopic expression of Ptfla can induce the generation of $\mathrm{dIL}^{\mathrm{A}}\left(\mathrm{Pax}^{+}\right)$and suppression of $\mathrm{dIL}^{\mathrm{B}}(\mathrm{Tl} \mathrm{x} 3)$ neurons in chick neural tube (Wildner et al. 2006). To test if these functions of Ptfla depend on the interaction of Ptfla and Rbpi, we performed in ovo electroporation experiments with the mutant Ptflaw298A . Electroporation of HH26 chick neural tubes with vectors expressing GFP and GFP plus Ptfla or Ptfla ${ }^{\text {W298A }}$ were analyzed at HH29-HH30 (48 h later) for Pax2 and Tlx3 as markers for $\mathrm{dIL}^{\mathrm{A}}$ and dIL $^{B}$ neurons, respectively (Fig. 2). Cells expressing the ectopic wild-type Ptfla were more likely to express Pax2 $\left(\mathrm{dIL}^{\mathrm{A}}\right)\left(48 \%\right.$ vs. $29 \%$ ) and less likely to express Tlx3 (dIL ${ }^{\mathrm{B}}$ ) ( $2 \%$ vs. $23 \%$ ) when compared with control electroporated cells (Fig. 2A-F, quantified in $\mathrm{J}, \mathrm{K}$ ). In contrast, expression of Ptf1a ${ }^{\mathrm{W} 298 \mathrm{~A}}$ did not alter marker expression from that seen in controls $(28 \%$ vs. $29 \%$ for Pax 2 and $24 \%$ vs. $23 \%$ for $\mathrm{Tlx} 3$ ), indicating loss of activity of the protein (Fig. 2G-I). Ectopic expression of Ptfla and Ptfla ${ }^{\text {W298A }}$ was confirmed by immunostaining the electroporated chick neural tubes using Ptfla-specific antibodies (Fig. 2F,I). These results demonstrate the requirement for the tryptophan residue in the ability of Ptfla to alter neuronal fate, and suggest that the interaction of Ptfla and Rbpj is required for Ptfla function in inducing $\mathrm{dIL}^{\mathrm{A}}$ and suppressing $\mathrm{dIL}^{\mathrm{B}}$ neurons in the neural tube.
A Ptf1a that can interact with Rbpj is required in vivo for the formation of GABAergic neurons in the dorsal horn of the spinal cord and the cerebellum

To identify the contribution in vivo of the Ptfla-Rbpi interaction to normal dorsal spinal cord development, we examined mutant mice that express the mutant form Ptf1a ${ }^{W 298 A}$ (Masui et al. 2007). Similar to the null mutant Ptf1a Cre/Cre (Kawaguchi et al. 2002), these animals die as neonates and lack a pancreas (Masui et al. 2007). In our initial characterization of the neural tube in these mutants, we used coimmunofluorescence with antiPtfla and anti-Ascll antibodies to examine if the mutant protein was made and present in the correct domain. In E10.5 neural tubes, Ptf1a is restricted to progenitors of dI4 interneurons (dP4), whereas Ascll is present in progenitors to dI3, dI4, and dI5 interneurons (Fig. 3A-A", dP3, dP4, dP5). The Ptf1a ${ }^{\mathrm{W} 298 \mathrm{~A}}$ protein in mutants homozygous for the Ptf1 $a^{W 298 A}$ allele is detected, and although it appears more diffuse within the cells and is at slightly lower levels, it is present in the dI4 progenitor domain similar to the wild-type protein (Fig. 3B, $\left.\mathrm{B}^{\prime}\right)$. The absence of detectable Ptf1a in the Ptf1a-null neural tubes demonstrates the specificity of the antibody (Fig. 3C, $\mathrm{C}^{\prime}$ ).

A first indication of a neural tube phenotype was the apparent increase in Ascll levels in the dI4 progenitor domain relative to that seen in wild type. Normally at this stage, Ascll levels are complementary to Ptfla levels in that they are generally low in the dI4 progenitors but high in the dI3 and dI5 progenitors /Glasgow et al. 2005). Within individual cells in the dI4 progenitor domain, cells with highest Ptfla have the lowest levels of Ascl1 (Fig. 3a-a", arrowheads), and vice versa (Fig. 3a-a", arrows). In contrast, in both the null Ptf1a and the variant Ptf1 ${ }^{W 298 A}$, Ascl1 levels were more uniform across dI3, dI4, and dI5 progenitor domains (Fig. 3B"-C"), and individual cells with or without $\mathrm{Ptf} 1 \mathrm{a}^{\mathrm{W} 298 \mathrm{~A}}$ protein have indistinguishable levels of Ascll (Fig. $\left.3 \mathrm{~b}-\mathrm{b}^{\prime \prime}\right)$. This in- 


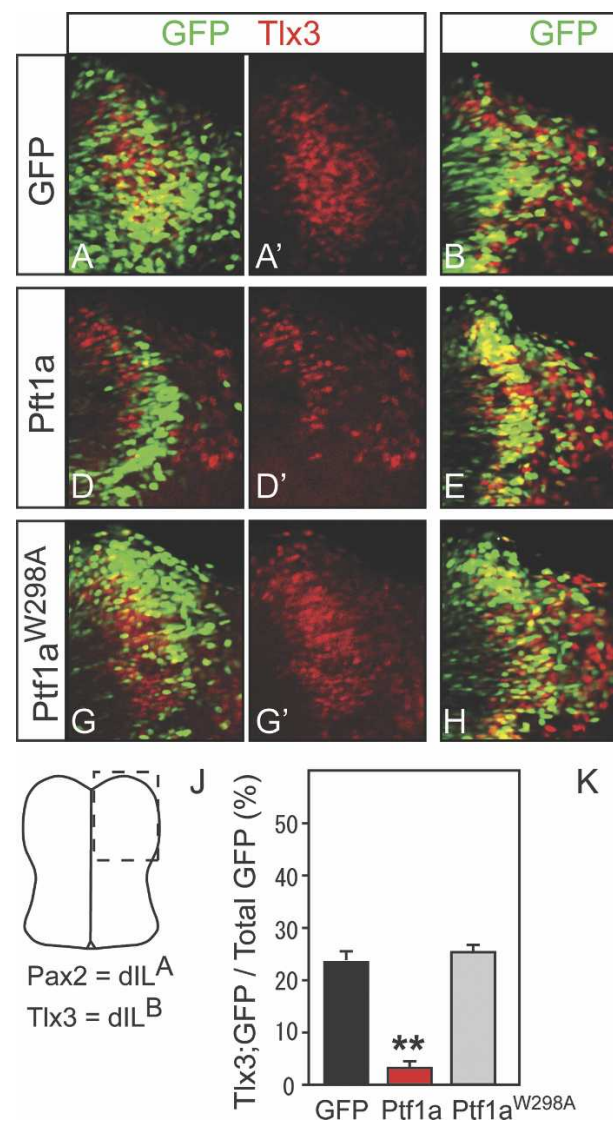

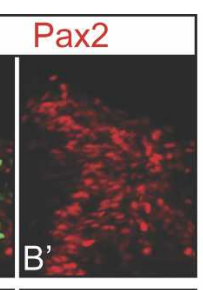
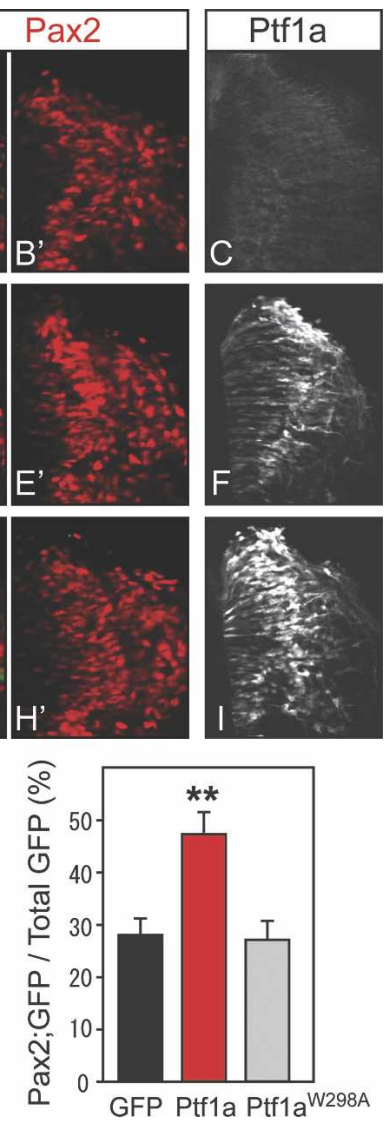

Figure 2. Ptf1a induction of $\mathrm{Pax} 2$ and suppression of Tlx3-expressing neurons in chick neural tube requires the interaction with Rbpj. Chick neural tubes were electroporated at $\mathrm{HH} 26$ with constructs expressing GFP $(A-C)$, Ptfla and GFP $(D-F)$, or Ptfla ${ }^{\mathrm{W} 298 \mathrm{~A}}$ and GFP $(G-I)$, and the effects on neural specification were assessed at HH29-HH30 using GFP fluorescence (green) and antibodies against Tlx3 (red in $A, A^{\prime}, D, D^{\prime}, G, G^{\prime}$ ) and Pax2 (red in $\left.B, B^{\prime}, E, E^{\prime}, H, H^{\prime}\right) .(C, F, I)$ Ectopic mouse Ptfla was detected with guinea pig anti-Ptfla antibody that does not recognize chick Ptfla. The proportion of $\mathrm{TlX}^{+}{ }^{+} \mathrm{GFP}^{+}$cells $(J)$ and $\mathrm{Pax}^{+}{ }^{+} \mathrm{GFP}^{+}$cells $(K)$ after electroporation of expression constructs for control GFP only (black), Ptfla plus GFP (red), or Ptf1a ${ }^{\text {W298A }}$ plus GFP (gray) was determined in the dorsal half of the electroporated side of the neural tube (see diagram for region where images were taken). Four embryos were analyzed per construct, and selected sections were between fore- and hindlimb levels in regions with $\mathrm{GFP}^{+}$cells. $\left(^{\star \star}\right) P<0.001$. crease in Ascll levels does not appear to be a consequence of loss of Notch signaling, since we detect no decrease in the levels of the Notch target Hes5 (data not shown). The results suggest Ptf1a ${ }^{\text {W298A }}$ has lost the ability to modulate Ascl1 levels.

The E10.5 dorsal neural tube has six populations of neurons defined by combinations of HD transcription factor expression (Helms and Johnson 2003). We analyzed five of these populations, comparing the wild type, the homozygous Ptf1 ${ }^{W 298 A}$, and the Ptf1a null. Just as for the Ptf1a null (Glasgow et al. 2005), in Ptf1a ${ }^{W 298 A / W 298 A}$ dorsal neural tube, the dI4 cells defined by location and coexpression of Pax 2 and $\mathrm{Lhx} 1 / 5$ were absent (Fig. 4A$\mathrm{A}^{\prime \prime}$, arrows), whereas the dI5 population, marked by Lmx1b, expanded dorsally into the dI4 domain (Fig. 4B$\mathrm{B}^{\prime \prime}$, arrows). In contrast, no significant change in cell number was observed in the dI2 (Lhx1/5), dI3 (Isl1), or dI6-V0 (Pax2/Lhx1/5) domains (see cell counts in Fig. 4C). Thus, the heterodimer of Ptfla with E-protein is not sufficient to specify dI4 neurons and suppress dI5, implicating the requirement for the Ptfla complex with Rpbj.

In the second wave of neurogenesis in the dorsal neural tube, two major interneuron populations arise out of a common progenitor domain. At E12.5, these neurons, $\mathrm{dIL}^{\mathrm{A}}$ and $\mathrm{dIL}^{\mathrm{B}}$, are marked by Pax 2 and $\mathrm{Lhx} 1 / 5\left(\mathrm{dIL}^{\mathrm{A}}\right)$, and Tlx3 and Lmx1b (dIL ${ }^{\mathrm{B}}$ ) (Helms and Johnson 2003). At E12.5, Ptf1a $a^{W 298 A / W 298 A}$ mutant neural tubes were found to have a dramatic reduction in dIL $^{\mathrm{A}}$ neurons and an increase in $\mathrm{dIL}^{\mathrm{B}}$ compared with wild type (Fig. 5). This is illustrated as a loss of Pax2- and Lhx1/5-positive cells (Fig. 5A, $\mathrm{A}^{\prime}$, counts in $\mathrm{C}$ ), and an increase in Lmx1b- and Tlx3-positive cells (Fig. 5B, $\mathrm{B}^{\prime}$, counts in C). Furthermore, it has been demonstrated that the $\mathrm{dIL}^{\mathrm{A}}$ neurons identified by Pax 2 and Lhx1/5 become GABAergic neurons in the dorsal horn and that $\mathrm{dIL}^{\mathrm{B}}$ neurons identified by Lmx1b and Tlx3 become glutamatergic /Cheng et al. 2004). Thus, we examined E16.5 mutant spinal cords for expression of GABAergic (Pax2, GABA) and glutamatergic (Tlx3,VGLUT2, GluR2/3) markers. Again, as was reported for the Ptf1a null (Glasgow et al. 2005), there was a dramatic loss of cells expressing the neurotransmitter GABA and the HD transcription factor Pax2 in the dorsal horn of the Ptf1aW298A/W298A compared with wild-type spinal cords (Supplemental Fig. 1A-B'). Conversely, these mutants have an increase over wild type in cells with markers associated with the glutamatergic phenotype (Supplemental Fig. 1C-E'). These results demonstrate the Ptf1a W298A/W298A mutant phenotype is nearly identical to the Ptf1a null in E10.5, E12.5, and E16.5 spinal neural tube. Thus, the reported role of Ptf1a as a switch between major GABAergic and glutamatergic neurons in the dorsal spinal cord is mediated through a Ptfla protein that requires the ability to complex with Rbpj. The Ptfla/E-protein heterodimer is not sufficient to control GABAergic identity.

Ptfla is also required for GABAergic neurons in cerebellum in mouse and human (Sellick et al. 2004; Hoshino et al. 2005; Pascual et al. 2007). Histological 


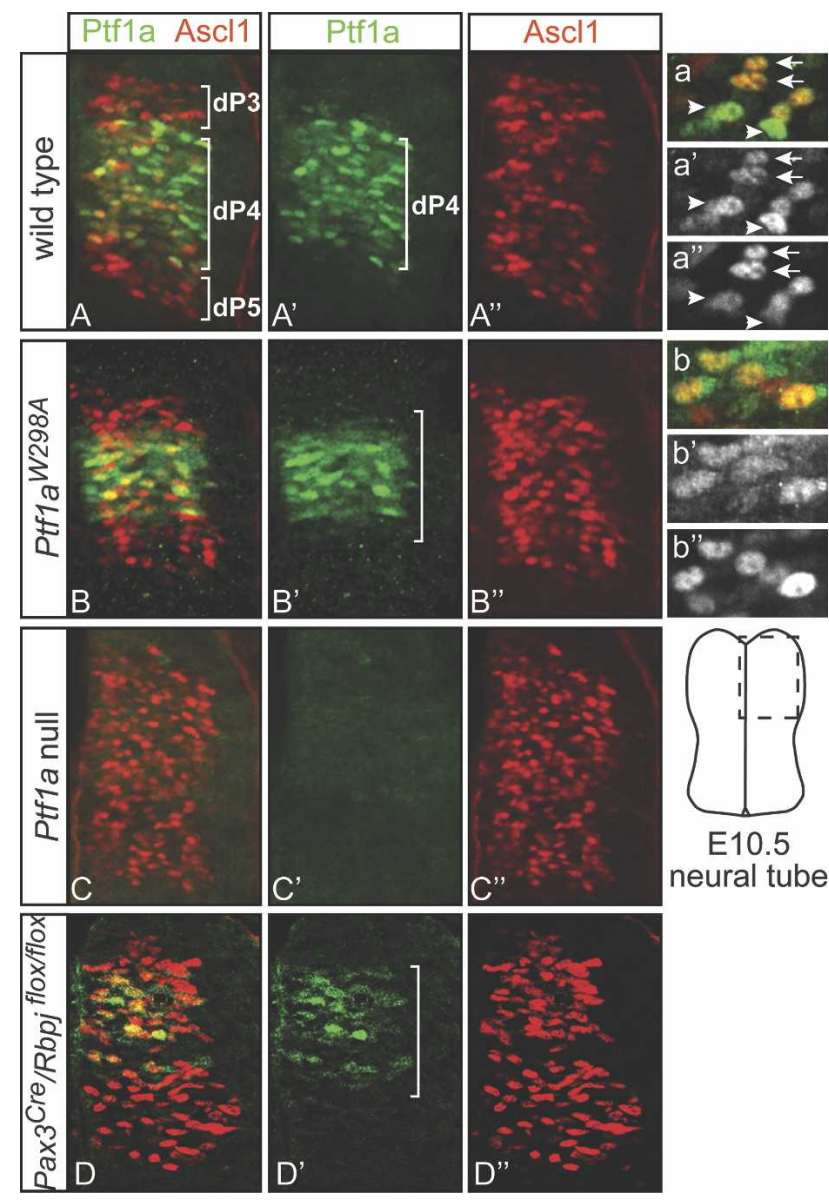

Figure 3. $\mathrm{Ptf} 1 \mathrm{a}^{\mathrm{W} 298 \mathrm{~A}}$ is detected in the progenitors to dI4 neurons but fails to repress Ascll levels. Immunofluorescence on neural tube transverse sections of wild-type $\left(A-A^{\prime \prime}\right)$, homozygous Ptf1a $a^{W 298 A}\left(B-B^{\prime \prime}\right)$, Ptf1a-null $\left(C-C^{\prime \prime}\right)$, and Pax ${ }^{\text {Cre }} / R b p i^{\text {flox/flox }}$ $\left(D-D^{\prime \prime}\right)$ mouse E10.5 embryos. Wild-type Ptfla and Ptf1a ${ }^{\text {W298A }}$ protein (green) is present in dI4 progenitors (dP4), although the number of positive cells in Ptf1a $a^{W 298 A / W 298 A}$ and Pax3Cre/ $R b p i^{\text {flox/flox }}$ neural tubes $\left(B^{\prime}, D^{\prime}\right)$ appears slightly decreased relative to that of wild type $\left(A^{\prime}\right)$. $\left(A^{\prime \prime}-D^{\prime \prime}\right)$ Ascll (red) levels appear to increase in the dI4 progenitor domain in all the mutant neural tubes. $\left(a^{\prime}, b^{\prime}\right)$ In high-magnification views, $\mathrm{Ptfl}^{\mathrm{a}} \mathrm{a}^{\mathrm{2} 28 \mathrm{~A}}$ is localized mainly to the nucleus, though its pattern is slightly disrupted compared with wild type. $\left(a-a^{\prime \prime}\right)$ The level of Ptfla in a cell is complementary to the level of Ascll in wild type. $\left(b-b^{\prime \prime}\right)$ This pattern is disrupted between $\mathrm{Ptf}_{1} \mathrm{a}^{\mathrm{W} 298 \mathrm{~A}}$ and Ascl1. Arrows and arrowheads indicate Ascll ${ }^{\text {high }} / \mathrm{Ptfl} \mathrm{a}^{\text {lowest }}$ cells and Ascl1 ${ }^{\text {lowest }} / \mathrm{Ptfl}^{\text {high }}$ cells, respectively.

analysis of sagittal sections at E16.5 showed aberrant morphology of the cerebellar primordia in $\mathrm{Ptfla}^{\mathrm{W} 298 \mathrm{~A}}$ mutant mice reminiscent of that reported for the null allele of Ptf1a (Fig. 5D-D"). The E16.5 Ptf1a W298A/W298A mutant cerebellum is smaller than wild type with a thickening of the Atoh1-expressing external germinal layer that contains progenitors to the major excitatory interneuron population in the cerebellum, the granule neurons (Supplemental Fig. 2A-B", arrows). The decreased size of the E16.5 cerebellum is largely due to a dramatic reduction of GABAergic neurons as determined by decreased immunoreactivity using antibodies to the transcription factor $\operatorname{Pax} 2$, to the neurotransmitter GABA, and to Calbindin, a marker for Purkinje cells, just as seen in the Ptf1a null (Fig. 5E-E"; Supplemental Fig. $\left.2 \mathrm{C}-\mathrm{E}^{\prime \prime}\right)$. In contrast to the loss of GABAergic neurons in

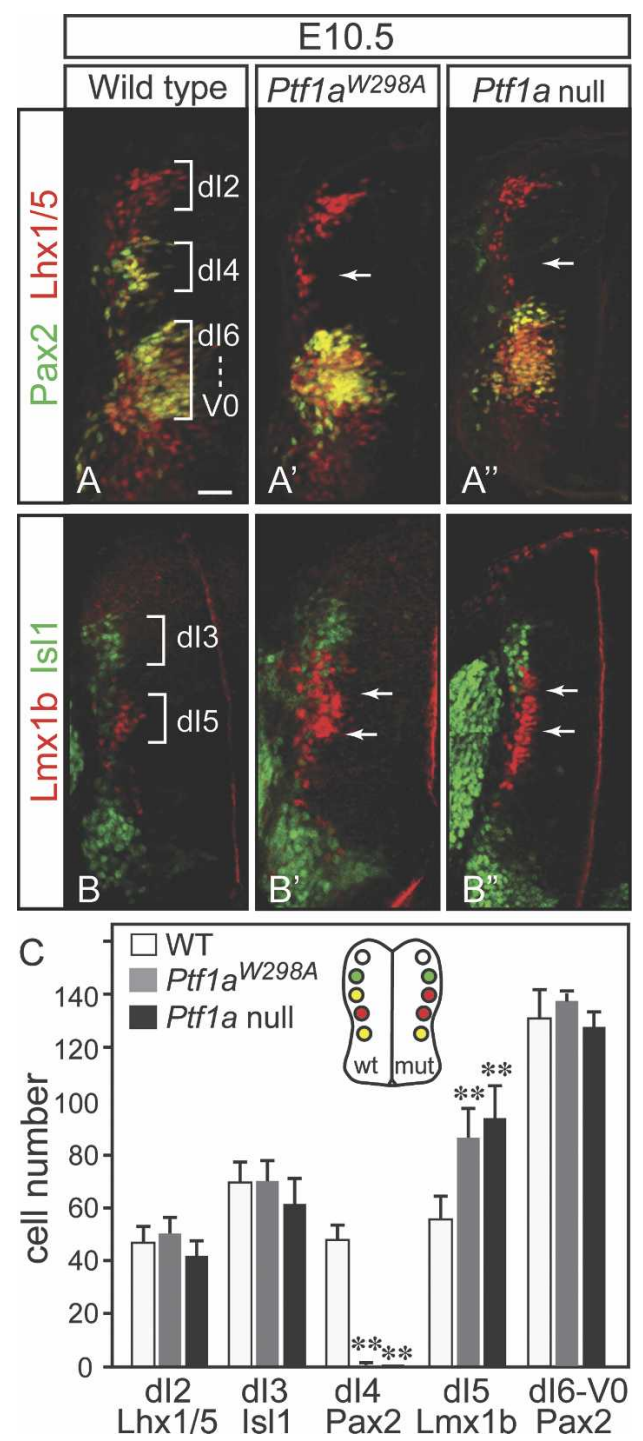

Figure 4. Dorsal interneurons dI4 are lost in mutants homozygous for Ptf1a W298A. Immunofluorescence on transverse sections of E10.5 neural tubes from wild-type $(A, B)$, homozygous Ptf1 $a^{\text {W298A }}\left(A^{\prime}, B^{\prime}\right)$, and Ptf1a-null $\left(A^{\prime \prime}, B^{\prime \prime}\right)$ embryos (only left half of neural tube is shown). ( $\left.A-A^{\prime \prime}\right)$ dI4 neurons (yellow) identified by location and colabeling with Pax 2 (green) and Lhx $1 / 5$ (red) are lost in the Ptf1a ${ }^{W 298 A}$ mutant and the Ptf1a null (arrows). There is no significant change in dI2 neurons identified by Lhx1/5 (red) or dI6-V0 neurons Pax 2 ;Lhx1/5 (yellow ventral to dI4). (B- $B^{\prime \prime}$ ) dI5 neurons identified by Lmx1b (red) are expanded dorsally into the dI4 domain in Ptf1a W298A mutants, as is seen in Ptf1a null (arrows), whereas dI3 and motor neurons marked by Isl1 (green) are not affected. These data are quantified in $C$ from sections in the upper limb level in at least four embryos of each genotype. The neural tube diagram summarizes the changes in neuronal populations detected in the Ptfla mutants relative to wild type. $\left(^{\star \star}\right) P<0.001$. Bar, $50 \mu \mathrm{m}$. 
both mutants, cells expressing Tbrl (Supplemental Fig. $2 \mathrm{~F}-\mathrm{F}^{\prime \prime}$ ), a marker for progenitors of glutamatergic neurons in deep cerebellar nuclei, are still present (Fink et al. 2006). Taken together, the ability of Ptfla to interact with Rbpj appears critical for the specification of GABAergic neurons not only in the developing spinal cord but also the cerebellum.

$R b p j$ is required specifically for GABAergic interneurons $d I 4$ and $d I L^{A}$ independent of its function as the effector of Notch signaling

The phenotype in the Ptf1 $a^{W 298 A / W 298 A}$ embryos demonstrates that the tryptophan 298 residue is essential for all described function of Ptfla, and implicates Rbpj as an
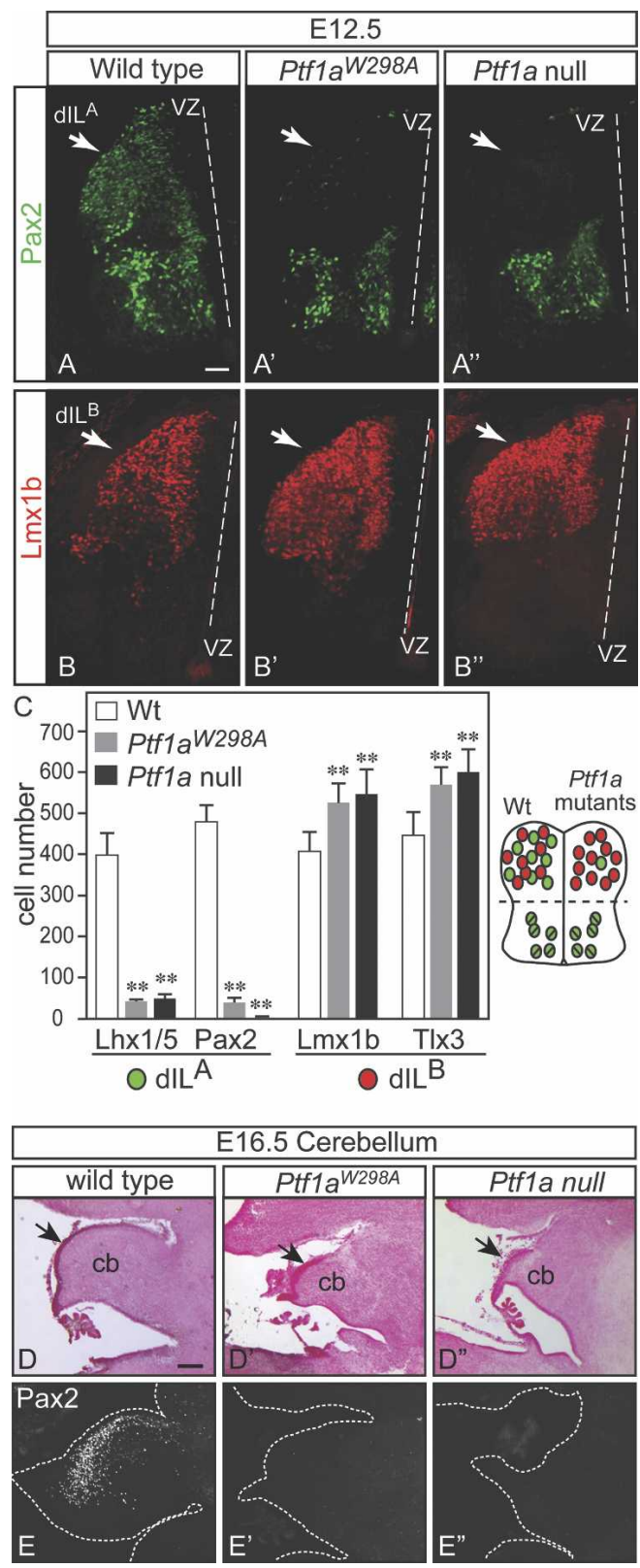

obligate cofactor. However, the known function of Rbpi is as the transcriptional effector of Notch signaling, which acts in the nervous system to inhibit neuronal differentiation (de la Pompa et al. 1997). To address the role of Rbpi in determining the identity of GABAergic interneurons in the dorsal spinal cord, we employed conditional mutagenesis of Rbpj (Tanigaki et al. 2002). A $\mathrm{Pax}^{\mathrm{Cre}}$ driver line that induces efficient recombination in the dorsal neural tube from E9 was used to delete Rbpi prior to the early neurogenic phase (Engleka et al. 2005). $\mathrm{Pax}^{\mathrm{Cre}} / \mathrm{Rbp}^{\text {flox/flox }}$ embryos have a decreased progenitor domain in the dorsal neural tube visualized with anti-Ki67, and precocious neuronal differentiation visualized with NeuN, relative to control embryos at E10.5 and E11.5 (Fig. 6A, $\mathrm{A}^{\prime}$ ). This result is in accordance with previous reports that demonstrate an important role for Notch signaling in the maintenance of neural progenitors (de la Pompa et al. 1997). To ascertain whether Rbpi also functions in specification of dI4 neurons, we examined the composition of the various dorsal neuron types at E10.5 in the $\mathrm{Pax}^{\mathrm{Cre}} / \mathrm{Rbp} \mathrm{f}^{\text {flox/flox }}$ embryos. Mutant mice suffer a complete loss of dI4 interneurons, which were identified by their position in the dorsal mantle zone and by their coexpression of Pax 2 and Lhx1/5 (Fig. $6 \mathrm{~B}, \mathrm{~B}^{\prime}$, see $\mathrm{D}$ for quantification). This was accompanied by an increase in the number of $\mathrm{dI} 2$ (Lhx1/5), dI3 (Isl1/2), and dI5 (Lmx1b/Tlx3) neurons (Fig. 6B-D). The number of dI 2 and dI 3 neurons was slightly increased in mutant mice, reflecting an overall increase in neurogenesis in the dorsal spinal cord. In contrast, the increase in the number of dI5 neurons was dramatic in the mutant embryos relative to control (Fig. 6C,D). This excess in the dI5 population accompanied by the absence of dI4 suggests the dI4 neurons assume dI5 identity in the absence of Rbpj. The combination of the loss of dI4 neurons with the increase in dI5 mimics the phenotype seen in Ptf1a mutants (Fig. 4; Glasgow et al. 2005). The loss of dI4 neurons in $\mathrm{Pax} 3^{\mathrm{Cre}} / \mathrm{Rbp} j^{\text {flox/flox }}$ embryos occurred even though Ptfla was present in dorsal progenitors (Fig. 3D).

Figure 5. Dorsal interneurons $\mathrm{dIL}^{\mathrm{A}}$ are lost in $P t f 1 a^{W 298 A} \mathrm{mu}-$ tants. Immunofluorescence on transverse sections of E12.5 neural tubes from wild-type $(A, B)$, homozygous $\operatorname{Ptf} 1 a^{W 298 A}\left(A^{\prime}, B^{\prime}\right)$, and Ptf1a-null $\left(A^{\prime \prime}, B^{\prime \prime}\right)$ embryos. Only the left half of the neural tube is shown (dashed line indicates the position of the ventricle). $\left(A-A^{\prime \prime}\right)$ Pax2 identifies dIL ${ }^{\mathrm{A}}$ neurons (green), which are essentially absent in Ptf1 $a^{W 298 A}$ and Ptf1a-null embryos specifically in the dorsal neural tube. $\left(B-B^{\prime \prime}\right)$ dIL $^{\mathrm{B}}$ neurons, marked by Lmxlb (red), increase in both the Ptf1 $a^{W 298 A}$ and Ptf1a-null embryos. These data plus those for Lhx $1 / 5$ ( $\mathrm{dIL}^{\mathrm{A}}$ marker) and Tlx3 (dIL ${ }^{\mathrm{B}}$ marker) are quantified in $C$ from sections in the upper limb level in six embryos of each genotype. $\left(^{\star \star}\right) P<0.001$. The neural tube diagram summarizes the changes in neuronal populations detected in the Ptfla mutants relative to wild type. (D$\left.E^{\prime \prime}\right)$ Sagittal sections of wild-type $(D, E), \operatorname{Ptf1} a^{W 298 A}\left(D^{\prime}, E^{\prime}\right)$, or Ptf1a-null $\left(D^{\prime \prime}, E^{\prime \prime}\right)$ mouse E16.5 cerebellar primordium $(\mathrm{cb})$ are shown with nuclear fast red histology demonstrating the decreased size of the cerebellum $(\mathrm{cb})$, the thickening of the EGL (arrow) in the mutants, and immunofluorescence detecting the GABAergic marker Pax2 $\left(E-E^{\prime \prime}\right)$. Dashed white line indicates tissue border. Bars: $A-B^{\prime \prime}, 50 \mu \mathrm{m} ; D-E^{\prime \prime}, 150 \mu \mathrm{m}$. 


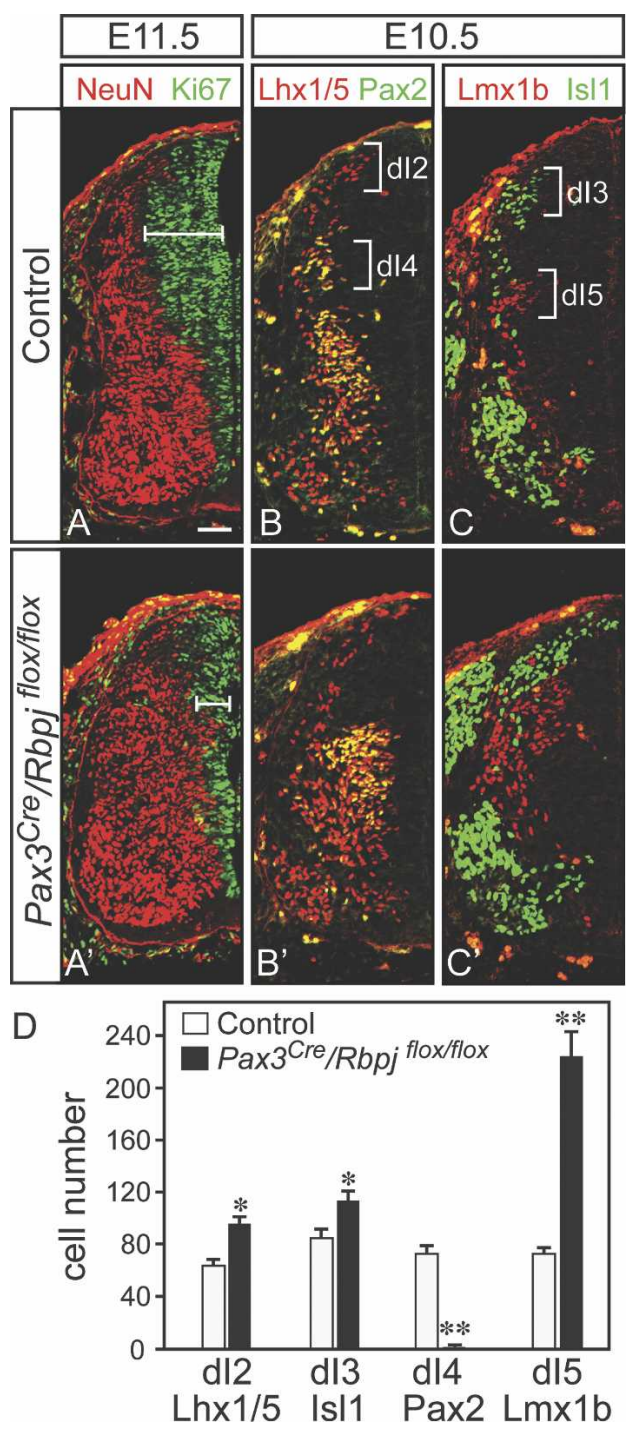

Figure 6. Rbpj is required to determine the identity of dI4 neurons. Immunofluorescence on transverse sections of E10.5 or E11.5 neural tubes from Control $\left(\mathrm{Pax}^{\mathrm{Cre}} / \mathrm{Rbpi}^{\text {flox } /+}\right)(A-C)$ and mutant $\mathrm{Pax} 3^{\mathrm{Cre}} / \mathrm{Rbpi}^{\text {flox/flox }}\left(A^{\prime}-C^{\prime}\right)$ embryos (only the left half of neural tube is shown). ( $\left.A, A^{\prime}\right)$ A decrease in the progenitor domain (indicated by the bar) and an increase in the neuronal domain in the dorsal neural tube of the $\mathrm{Pax} 3^{\mathrm{Cre}} / \mathrm{Rbpi} \mathrm{f}^{\text {flox } / \text { flox }}$ mutants were detected using Ki67 (green) and NeuN (red), respectively. $\left(B, B^{\prime}\right)$ dI2 (Lhx1/5, red) are increased while dI4 (Pax2/ Lhx1/5, yellow) are lost in the Pax $3^{\text {Cre }} / \mathrm{Rbpi}^{\text {flox/flox }}$ mutant. $\left(C, C^{\prime}\right)$ dI3 (Isl1, green) and dI5 (Lmx1b, red) neurons are both increased in the Pax $3^{\mathrm{Cre}} / \mathrm{Rbp}^{\text {flox/flox }}$ relative to controls. The dramatic increase in dI5 neurons and the loss of dI4 neurons suggests that dI4 assume the identity of dI5 neurons in the absence of Rbpj. These data are quantified in $D$ from three embryos each using sections from the upper limb level. Error bars represent standard error. $\left(^{\star}\right) P<0.05 ;\left(^{\star \star}\right) P<0.001$. Bar, $50 \mu \mathrm{m}$.

Notably, the changes in Ptfla and Ascl1 levels in the $\mathrm{Pax}^{\mathrm{Cre}} / \mathrm{Rbpi}^{\text {flox/flox }}$ mutants appear similar to those detected in the Ptf1a $a^{W 298 A / W 298 A}$ mutants (Fig. 3, cf. B-B" and $\left.\mathrm{D}-\mathrm{D}^{\prime \prime}\right)$. Taken together, the similarity in phenotype between the Ptfla and Rbpj mutants provides in vivo evidence supporting the requirement of the Ptfla-Rbpj complex in determining neuronal identity in dI4 versus dI5 interneurons.

The dorsal progenitor domain of $\mathrm{Pax} 3^{\mathrm{Cre}} / \mathrm{Rbp} \mathrm{j}^{\text {flox/flox }}$ mice was depleted by E12, which precluded further investigation of the role of Rbpj in the generation of $\mathrm{dIL}^{\mathrm{A}}$ and $\mathrm{dIL}^{\mathrm{B}}$ neurons (data not shown). To assess the function of Rbpj during this second neurogenic phase, we generated a BAC transgenic mouse strain that expresses a tamoxifen-inducible Cre recombinase under the control of the $\mathrm{Pax} 7$ locus (Fig. 7A). Recombination induced by the $\operatorname{Pax} 7^{C r e E R T 2}$ transgene was investigated using the ROSA26R reporter line that expresses $\beta$-galactosidase after Cre-mediated recombination (Soriano 1999). After administration of tamoxifen at E10.5, efficient recombination was observed in the ventral part of the alar plate by E12.5 (Fig. 7B). We detected no obvious depletion of the progenitor domain in the $\operatorname{Pax} 7^{\text {CreERT2 }} / R b p j^{\Delta / \text { flox }}$ mutant mice at E12.5, $2 \mathrm{~d}$ after tamoxifen administration (Fig. $7 \mathrm{C}, \mathrm{D})$, although depletion of progenitors was observable at E13.5 (data not shown). However, there was a significant reduction in the number of newborn $\mathrm{dIL}^{\mathrm{A}}$ neurons (Pax2 and Lhx1/5), while the number of $\mathrm{dIL}^{\mathrm{B}}$ neurons (Lmx1b and Tlx3) was increased (Fig. 7E,F, see G for quantification). Taken together, these results demonstrate a role for Rbpj in determining the identity of the GABAergic neurons $\mathrm{dI} 4$ and $\mathrm{dIL}^{\mathrm{A}}$, while suppressing the identity of the glutamatergic neurons $\mathrm{dI} 5$ and $\mathrm{dIL}^{\mathrm{B}}$, with little effect on the other dorsal interneuron cell types.

In order to separate the role of Rbpj in the Ptfla complex versus its role in the Notch signaling pathway, we used a mouse strain that expresses, after Cre-induced recombination, a dominant-negative variant of Mastermind-like (DNMaml) under the control of the ROSA26 locus ( $\mathrm{Tu}$ et al. 2005). Maml factors act with NICD to form a transcription activation complex with Rbpj. The dominant-negative Maml lacks its activation domain and is thought to block Notch signaling by forming an inactive complex with NICD and Rbpj (Tu et al. 2005). We analyzed the dorsal spinal cord of control and mutant mice (Pax3 $\left.3^{\mathrm{Cre}} / \mathrm{DNM} \mathrm{Nml}\right)$ at E12.5 with Ki67 and the neuronal marker Tuj1, and observed a partial depletion of the progenitor domain in mutants when compared with control, consistent with a reduction of Notch signaling (Fig. 7C,H). However, in contrast to changes seen in the Rbpj mutants, there was no loss of $\mathrm{dIL}^{\mathrm{A}}(\mathrm{Pax} 2)$ neurons. Instead, there was a minor decrease in the $\mathrm{dIL}^{\mathrm{B}}$ population (Fig. 7I, quantified in $\mathrm{J}$ ). This decrease in $\mathrm{dIL}^{\mathrm{B}}$ is consistent with a previous report that demonstrated Notch signaling biases the dIL progenitor to a dIL ${ }^{B}$ fate (Mizuguchi et al. 2006). These results demonstrate two functions for Rbpj in dorsal neural tube development. Rbpj acts both in a complex with Ptfla and an E-protein to specify dI4 and $\mathrm{dIL}^{\mathrm{A}}$ neurons, and independently, in a complex with Maml, to transduce Notch signals that maintain neural progenitors and suppress neuronal differentiation (Fig. 8). 
Figure 7. Rbpi is required to determine the identity of $\mathrm{dIL}^{\mathrm{A}}$ neurons independent of its role in Notch signaling. $(A)$ Diagram of the Pax ${ }^{\text {CreERT2 }}$-BAC transgenic mouse strain used to delete Rbpj during the second neurogenic phase of neural tube development. (B) $\beta$-gal expression in a PaX $7^{\text {CreERT2/ROSA26R }}$ E12.5 embryo treated with tamoxifen at E10.5 demonstrates active Cre recombination in the dorsal neural tube. Immunofluorescence images on E12.5 neural tubes after 10.5-dpost-coitum (dpc) tamoxifen administration of control $(C, E)$ and $P a x 7^{C r e E R T 2} / R b$ $p^{\text {flox/s }}(D, F)$, or Pax3 ${ }^{\text {Cre }} / D N M a m l(H, I)$ mutants. Antibodies used include Ki67 (red) and Tuj1 (green) to distinguish progenitor and differentiation domains $(C, D, H)$, or Pax2 (green) and $\mathrm{Lmx} 1 \mathrm{~b}$ (red) to distinguish $\mathrm{dIL}^{\mathrm{A}}$ and $\mathrm{dIL}^{\mathrm{B}}$ populations $(E, F, I) \cdot(E, F)$ The boxed areas are shown at higher magnification in the insets and indicate the domain that was quantified for the number of $\mathrm{dIL}^{\mathrm{A}}$ and $\mathrm{dIL}^{\mathrm{B}}$ neurons (shown in G). This domain was used since Cre recombination induced by tamoxifen at $10.5 \mathrm{dpc}$ was efficient in this region /see $B)$ and it contains newly born neurons. $(J)$ The number of $\mathrm{dIL}^{\mathrm{A}}$ (Pax2) and $\mathrm{dIL}^{\mathrm{B}}$ (Tlx3) cells in Pax3 $3^{\text {Cre }} /$ DNMaml embryos relative to control was quantified in the entire dorsal and neural tube, reflecting the recombination efficiency by $\mathrm{Pax} 3^{\mathrm{Cre}}$. Data quantified in $G$ and $J$ are from three embryos each using sections from the upper limb level. Error bars represent standard error. $\left.\left(^{\star}\right) P<0.05 ;{ }^{\star \star}\right) P<0.001$. Bars: 50 $\mu \mathrm{m}$; insets in $E, F, 20 \mu \mathrm{m}$.

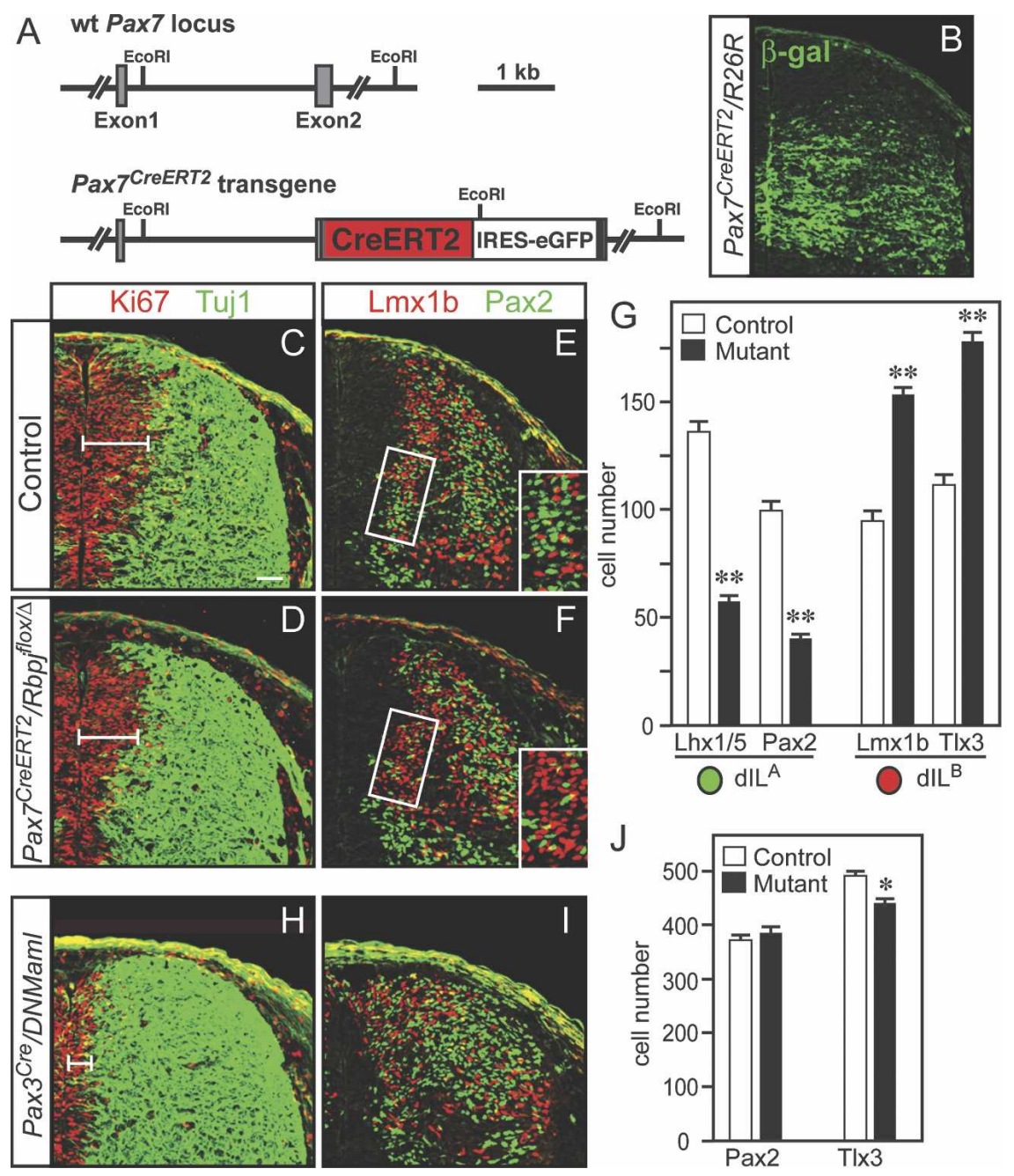

\section{Discussion}

Requirement for a Ptf1a-Rbpj complex in development of specific GABAergic neuronal populations

Ptfla is an unusual bHLH transcription factor. Like other class II bHLH factors, it heterodimerizes with an E-protein such as Tcf12 and binds the hexameric E-box DNA sequence. What is unique to Ptfla is that it also can form a trimeric complex by direct binding to Rbpj or Rbpil, forming a complex that binds a compound DNA sequence that includes the E-box plus a TC-box, a consensus Rbpj site (Fig. 1A; Beres et al. 2006). In this study, we provide in vivo evidence that a Ptfla-Rbpj complex is essential in neural development for determining the identity of specific populations of GABAergic neurons while suppressing neighboring glutamatergic neurons. First, embryos homozygous for the Ptf1a $a^{W 298 A}$ allele that encodes a Ptfla variant deficient in Rbpj binding fail to generate GABAergic neurons in the dorsal spinal cord (dI4 and $\mathrm{dIL}^{\mathrm{A}}$ ) and cerebellum. Second, in contrast to wild-type Ptfla, the Ptf1a ${ }^{\mathrm{W} 298 \mathrm{~A}}$ mutant protein cannot induce the generation of $\mathrm{dIL}^{\mathrm{A}}(\mathrm{Pax} 2)$ and the suppression of $\mathrm{dIL}^{\mathrm{B}}$ (Tlx3) neurons when overexpressed in the chick neural tube. Third, conditional loss of Rbpj demonstrates its requirement in determining the identity of dI4 and $\mathrm{dIL}^{\mathrm{A}}$ neurons but not the other dorsal neuronal populations. And fourth, in both the Ptf $1 \mathrm{a}^{\mathrm{W} 298 \mathrm{~A}}$ mutants and the conditional loss of Rbpi, the absence of GABAergic neurons is countered by an increase in the neighboring glutamatergic populations. Thus, we demonstrate that a unique transcription complex containing Ptfla and Rbpj is the functional complex in vivo for determining the balance of inhibitory and excitatory neurons in the dorsal spinal cord. The classic form of the bHLH heterodimer with E-protein is not sufficient to replace the PtflaRbpj function. And finally, the requirement for Rbpj in the Ptfla-Rbpj complex is unique for Rbpj biology in that it is distinct from its role in transducing Notch signals.

Human mutations in PTF1A support the conclusion that in vivo the functional complex requires PTF1ARbpi protein-protein interaction. The human mutations of PTF1A result in pancreatic agenesis and cerebellar hypoplasia (Hoveyda et al. 1999; Sellick et al. 2004). These mutations resulted in C-terminal-truncated PTF1As that 
leave the bHLH domain intact but delete the tryptophancontaining peptide region shown in mouse to be required for Ptfla-Rbpj complex formation. Originally, it was suggested that the human phenotype was due to the loss of bHLH heterodimer formation or stability. However, it was subsequently shown that the truncated human proteins could still form heterodimers with E-protein but not heterotrimers with Rbpi or Rbpil, and they were devoid of transcriptional activity in cell transfection assays (Beres et al. 2006). Therefore, as in the Ptf1a ${ }^{W 298 A}$ mouse mutant analyzed here (and in Masui et al. 2007), the human mutations disrupt formation of the PTF1A-RBPJ complex, resulting in the pancreatic and cerebellar phenotypes reported.

\section{Transcription factor control of neuronal cell type identity in the dorsal spinal cord}

We demonstrate that Ptfla and Rbpi are essential for the transcriptional control of genes that generate the balance of inhibitory and excitatory neurons. The Ptfla-Rbpj complex along with Ascll controls neuronal specification upstream of HD transcription factors such as Pax2, Lhx1/5, Tlx3, and Lmx1b. In particular, Ptfla is essential for Pax2 expression (dI4) in the dorsal neural tube, whereas Ascl1, with Gsh1/2, is required for Tlx3 (dI5) (Glasgow et al. 2005; Helms et al. 2005; Mizuguchi et al. 2006). In the absence of Ptfla, the dI4 neurons assume a dI5-like identity (Glasgow et al. 2005). This increase in dI5-like neurons may be a consequence of the up-regulation of Ascll that occurs in cells that have lost PtflaRpbj function, shown here in the Ptf1aW298A and Pax $3^{\text {Cre }} /$ Rbpi $^{\text {flox/flox }}$ mutants (Fig. 3). Thus, in this early phase of dorsal spinal cord development, part of PtflaRbpj function is to cell-autonomously suppress Ascll levels while inducing dI4-specific genes.

In the second neurogenic phase in the dorsal neural

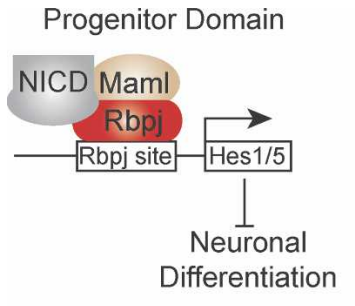

Figure 8. Distinct functions for the two independent Rbpj-containing transcription complexes. Diagram depicting the two Rbpi-containing complexes. Rbpj with the NICD and Maml enhance expression of Hes1 and Hes5, which in turn inhibit neuronal differentiation and maintain the progenitor domain. DNA binding is through a consensus binding site for Rbpj. The PTF1 complex containing Rbpj with Ptfla and an E-protein such as Tcf12 is distinct and binds a bipartite sequence that includes an E-box plus a TC-box. The TC-box is similar to the Rbpj consensus site, but not all TC-boxes serve as Rbpj-binding sites (Beres et al. 2006). The PTF1 transcription factor complex determines neuronal identity by inducing GABAergic-specific genes and suppressing glutamatergic-specific genes. tube, neurons are generated from a progenitor domain that has Ptfla- and Ascll-expressing cells dispersed throughout the dorsal progenitor zone. The current model for balancing the generation of excitatory and inhibitory neurons in this region places Ascll in progenitor cells where it cell-autonomously regulates Ptfla to promote the dIL ${ }^{\mathrm{A}}$ lineage, or non-cell-autonomously to activate the Notch pathway that biases cells to the $\mathrm{dIL}^{\mathrm{B}}$ lineage (Mizuguchi et al. 2006). Inhibition of Notch signaling through Rbpi and Maml in the dorsal neural tube resulted in a subtle decrease specifically in the $\mathrm{dIL}^{\mathrm{B}}$ population, consistent with this model (Fig. 7J). However, the most dramatic effect on the balance of $\mathrm{dIL}^{\mathrm{A}}$ and $\mathrm{dIL}^{\mathrm{B}}$ populations was through a Notch-independent role for Rbpj in a complex with Ptfla. In this case, dIL ${ }^{\mathrm{A}}$ neurons take on the identity of $\mathrm{dIL}^{\mathrm{B}}$-like neurons and thus completely disrupt the balance of inhibitory and excitatory neurons. So although Notch signaling modulates the balance of the $\mathrm{dIL}^{\mathrm{A}}$ and $\mathrm{dIL}^{\mathrm{B}}$ lineages, Rbpj in a Notch-independent complex is essential for determining identity of the dorsal horn GABAergic neurons.

\section{Ptf1a functions with Rbpi in multiple developmental pathways}

Cerebellar development serves as another model for uncovering the molecular logic used to generate the correct balance of excitatory and inhibitory neurons in a neuronal network. Ptfla plays a central role here as well, and similar to the dorsal spinal cord, Ptfla is required for generation of the major populations of GABAergic neurons including Purkinje, basket, stellate, and golgi cells (Hoshino et al. 2005; Pascual et al. 2007). Ptfla suppresses the glutamatergic phenotype, because in the Ptf1a-null mouse, Ptfla lineage cells are at least partially misspecified to granule-like cells in the external granule layer (Pascual et al. 2007). The cerebellum in Ptf1 $a^{\text {W298A }}$ mutant mice is similar in phenotype to the Ptf1a null. While we did not demonstrate a similar requirement for Rbpj in this region of the developing brain, we propose that the Ptf1a-Rbpi complex is a common mechanism for maintaining the balance of inhibitory and excitatory neurons wherever Ptfla is expressed. However, the Ptfla-Rbpi complex cannot be required for specification of all GABAergic neurons, because Ptfla is not present in all brain regions containing these neurons (e.g., ventral spinal cord, tectum, and cortex [Glasgow et al. 2005]). Thus, other mechanisms for transcriptional control of the GABAergic phenotype must be in play. For example, Ascll functioning with the Hes-related bHLH factor Helt has been implicated in the GABAergic phenotype in the midbrain and cortex (Fode et al. 2000; Miyoshi et al. 2004; Guimera et al. 2006; Nakatani et al. 2007).

Ptfla is not restricted to the developing nervous system; in fact, Ptfla was originally identified as a key transcriptional regulator in pancreas (Krapp et al. 1996; Rose et al. 2001). In mature pancreas, Ptf1a forms a complex with an E-protein and Rbpil that is required in acini for expression of secretory digestive enzymes (Beres et al. 2006). However, mouse knockouts of Ptfla revealed that 
it functions earlier in the developing pancreas at a stage when Rbpil is not present (Krapp et al. 1998; Kawaguchi et al. 2002). In a study performed in parallel with the study reported here, Ptfla was shown to be in a complex with Rbpj and an E-protein early in pancreas development (Masui et al. 2007). The Ptf1a ${ }^{\text {W298A }}$ variant was used to demonstrate that the interaction between Ptfla and $\mathrm{Rbpj}$ is required for early functions controlling pancreatic growth, morphogenesis, and lineage fate decisions. Taken together, in each Ptfla-expressing tissue examined, the functional form for this transcription factor is in a nonclassical bHLH complex, one that includes $\mathrm{Rbpj}$ or Rbpl, and is independent of Notch.

\section{Two distinct roles for Rbpj in dorsal neural tube development}

Rbpj has been described as a bifunctional protein that acts both as a transcriptional activator and repressor by associating with various cofactors, and it plays a pivotal role in control of cell fate decisions in the developmental programs of a variety of tissues (Honjo 1996). Although autoactivation of the Drosophila ortholog of Rbpi, Suppressor of Hairless, during development of mechanosensory organs has been reported as a Notch-independent function for Suppressor of Hairless, known molecular functions of $\mathrm{Rbpj}$ in vertebrates are through its function as the transcriptional regulator of Notch signaling (Barolo et al. 2000). In this role, Rbpj functions as a DNAbinding factor and mediates the transcriptional effects of Notch by associating with the protease-cleaved NICD and its coactivator Maml. Notch signaling through an Rbpi-dependent mechanism activates expression of the inhibitory bHLH factors Hes 1 and Hes 5 to suppress neuronal differentiation and maintain cells in a progenitor state (Fig. 8; Ohtsuka et al. 1999; Gaiano et al. 2000). Our data confirm that Rbpj, through transducing Notch signals, is required in this process since blocking the activation of the complex with dominant-negative Maml resulted in depletion of the progenitor domain and precocious neuronal differentiation (Figs. 6, 7).

Our data also describe a novel role for Rbpj in neural development distinct from its function in maintaining the neural progenitor state. Rbpj is required to determine the identity of GABAergic neurons over glutamatergic neurons in specific CNS regions, and this function is independent of the Notch signaling cascade. Although this function of Rbpj could involve its role as a repressor, our data with the Ptf1a ${ }^{\mathrm{W} 298 \mathrm{~A}}$ variant strongly implicate a Ptfla-Rbpj1 complex. PTF1, the transcription complex comprising Ptfla, Rbpj, and an E-protein, functions through regulating the expression of specific targets by recognition of its compound DNA-binding consensus containing an E-box and a TC-box (Beres et al. 2006). This transcription complex induces expression of GABAergic-specific genes such as Pax2, Lhx1/5, and GABA, while inhibiting expression of glutamatergic genes such as Tlx3, Lmx1b, and Vglut (Fig. 8). Which, if any, of these genes are direct targets is not yet known. Future studies defining target genes directly regulated by the PTF1 transcription complex will begin to provide a molecular framework for understanding function of this novel complex, and in turn address the important question of how neuronal networks are generated during early development.

\section{Materials and methods}

Mouse strains

Ptf1a ${ }^{C r e}\left(p 48^{C r e}\right)$ mutant mice have been described previously (Kawaguchi et al. 2002) and are used here as the Ptf1a null. Rbpi flox (Tanigaki et al. 2002), Pax ${ }^{\text {Cre }}$ (Engleka et al. 2005), DNMAML (Tu et al. 2005), and ROSA26R (Soriano 1999) mice have been described previously. $R b p i^{f^{l o x} /+}$ mice were used to generate the $R b p i^{\Delta}$ allele by the use of a Cre-deleter strain (Schwenk et al. 1995).

Ptf1a ${ }^{W 298 A}$ mutant mice were generated by recombinase-mediated cassette exchange (Feng et al. 1999) using a two-step staggered selection strategy (Long et al. 2004) to insert the singlecodon W298A mutation into the endogenous Ptf1a locus using a mouse embryonic stem (ES) cell line that was previously engineered to contain a loxed cassette acceptor allele (M.A. Magnuson, unpubl.). ES cells containing the mutated Ptf1a gene sequences were then injected into blastocysts (Masui et al. 2007). A Frt-flanked hygromycin resistance cassette was removed by crossing to a FlpE-expressing transgenic mouse (Rodriguez et al. 2000) prior to analysis. Genotyping for Ptf1a ${ }^{W 298 A}$ mutant mice was performed using a PCR protocol that distinguishes the 2-base-pair (bp) difference (TGG) to (GCG) using the following primers: 5'-TCATCCGTACAGCTAAAGTGTG-3' and $5^{\prime}$-TCTGTCAAAGGTGCTTCAGG-3' for the wild-type Ptf1a locus $(\sim 300 \mathrm{bp})$, and 5'-TCATCCGTACAGCTAAAG

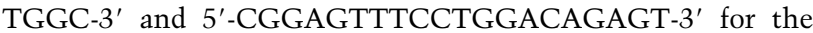
Ptf1a ${ }^{W 298 A}$ mutant locus ( 300 bp).

The $\operatorname{Pax} 7^{\text {CreERT2 }}$ mice were generated as BAC transgenics using pronuclear injection. A $185-\mathrm{kb}$ BAC clone RP23-387L10 (RZPD) containing the Pax 7 locus was modified by homologous recombination in bacteria (Lee et al. 2001) using a cassette encoding the entire sequence of CreERT2 (containing the initiating ATG codon) and IRES-eGFP-pA designed to replace the second exon of Pax7. Exon 1 was modified to remove possible ATG codons. The linearized $\mathrm{Pax} 7^{\mathrm{CreERT}}$-BAC was injected into pronuclei of fertilized eggs. Four transgenic founders were obtained and screened for Cre-induced recombination. The transgenic founder that induced the highest recombination rate in the spinal cord was selected. Genotyping of $\operatorname{Pax} 7^{\mathrm{CreERT2}}$ transgenic mice was performed using the following primers: $5^{\prime}$-CTC CCCCACACTAACTGCAT-3' and 5'-ATGTTTAGCTGGCC CAAATG-3' giving a PCR product of $380 \mathrm{bp}$.

Embryos were staged based on assumed copulation at E0, halfway through the dark cycle. Tamoxifen (Sigma-Aldrich) was dissolved at a concentration of $20 \mathrm{mg} / \mathrm{mL}$ in sunflower oil and administered to pregnant females at $100 \mathrm{mg} / \mathrm{kg}$ (Joyner and Zervas 2006). Embryos were dissected for analysis $48 \mathrm{~h}$ after tamoxifen treatment.

\section{Plasmid construction}

All chick electroporations and COS cell coimmunoprecipitation experiments used the expression vector pMiWIII, which derives expression through a chick $\beta$-actin promoter (Suemori et al. 1990; Matsunaga et al. 2001). Mouse Ptf1a and Ptf1a ${ }^{\text {W298A, }}$ human RBPJ, and human TCF12 coding regions (Beres et al. 2006) were subcloned as PCR products with NcoI and XbaI ends 
into a modified pMiWIII vector that results in fusion of five myc tags at the $\mathrm{N}$ terminus of the proteins. Plasmids were sequenceverified.

\section{Immunofluorescence}

Embryos at E10.5 and E12.5 were dissected in ice-cold $0.1 \mathrm{M}$ sodium phosphate buffer ( $\mathrm{pH} 7.4$ ), fixed in $4 \%$ formaldehyde for $2 \mathrm{~h}$ at $4^{\circ} \mathrm{C}$, and washed three times in $0.1 \mathrm{M}$ sodium phosphate buffer ( $\mathrm{pH} 7.4)$ for $2 \mathrm{~h}$. For E16.5 spinal cords and brains, the tissues were dissected out, fixed in $4 \%$ formaldehyde overnight at $4^{\circ} \mathrm{C}$, and washed overnight with $0.1 \mathrm{M}$ sodium phosphate buffer (pH 7.4). Embryos and dissected tissues were sunk overnight in $30 \%$ sucrose in $0.1 \mathrm{M}$ sodium phosphate buffer (pH 7.4), embedded in OCT, and cryosectioned at 12-30 $\mu \mathrm{m}$. All sections of neural tubes and spinal cords are from the upper limb level.

Immunofluorescence was performed using the following primary antibodies: rabbit anti-calbindin (1:500; Sigma), rabbit anti-GABA (1:1000; Sigma), rabbit anti-GluR2/3 (1:100; Chemicon), rabbit anti-Islet1/2 (1:5000; Tsuchida et al. 1994), guinea pig anti-Islet1/2 (1:20,000; gift from $\mathrm{T}$. Jessell), mouse antiLhx1/5 (1:100; 4F2; Developmental Studies Hybridoma Bank), guinea pig anti-Lmx1b (1:5000; Müller et al. 2002), mouse antiMash1 (1:1000; Lo et al. 1991), rabbit anti-Math1 (1:100; Helms and Johnson 1998), rabbit anti-Pax2 (1:1000; Zymed), rabbit anti-Tlx3 (1:20,000; gift from T. Müller and C. Birchmeier), guinea pig anti-VGLUT2 (1:2500; Chemicon), goat anti- $\beta$-Gal (1:500; Biogenesis), mouse anti-NeuN (1:1000; Chemicon), rat anti-Ki67 (1:50; DakoCytomation), and mouse anti-TuJ1 (1:1000; Covance). Guinea pig polyclonal antisera to Ptf1a (1:5000) were raised against amino acids $11-235$ of recombinant mouse Ptfla (GenBank NM_018809) fused with glutathione-Stransferase (Ptfla-GST expression plasmid was a gift from $\mathrm{H}$. Edlund). The specificity of the antisera was confirmed by staining E10.5 neural tube sections from wild-type and Ptf1a-null embryos (Fig. 3). Fluorescence imaging and cell counts of specific neuronal cell types were carried out on a Bio-Rad MRC 1024 or Zeiss LSM Pascal confocal microscope. For each experiment, multiple sections from at least three different animals were analyzed.

\section{Chicken in ovo electroporation}

Fertilized White Leghorn eggs were obtained from the Texas A\&M Poultry Department and incubated for $5 \mathrm{~d}$ at $39^{\circ} \mathrm{C}$. Solutions of supercoiled plasmid DNA $(0.5 \mu \mathrm{g} / \mu \mathrm{L})$ in PBS/0.02\% Trypan Blue were injected into the lumen of the closed neural tube at stage $\mathrm{HH} 26$, and embryos were electroporated as described previously (Muramatsu et al. 1997; Funahashi et al. 1999; Nakada et al. 2004; Wildner et al. 2006). An expression vector with nuclear localized GFP (pCIG) (Megason and McMahon 2002) was coinjected as a control to monitor efficiency and extent of electroporation. Embryos were harvested $48 \mathrm{~h}$ later at HH29-HH30, fixed with $4 \%$ formaldehyde for $1 \mathrm{~h}$, and processed as above for cryosectioning and immunofluorescence.

\section{COS transfection and coimmunoprecipitation}

COS cells were transiently transfected individually with Ptfla,

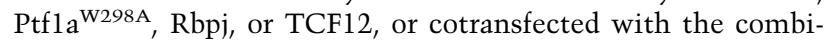
nations indicated in Figure 1 using Fugene 6 Transfection Reagent (Roche). All proteins expressed were myc-tagged and expressed using pMiWIII expression vector. After $48 \mathrm{~h}$, the cells were washed with ice-cold PBS, and homogenized in lysis buffer containing $50 \mathrm{mM}$ Tris- $\mathrm{Cl}$ (pH 7.5), $5 \mathrm{mM} \mathrm{MgCl}_{2}, 100 \mathrm{mM} \mathrm{KCl}$, $1 \mathrm{mM}$ DTT, $0.2 \%$ NP-40, $1 \mathrm{mM}$ PMSF, and protease inhibitor cocktail. After centrifugation at 20,000 $\mathrm{g}$ for $20 \mathrm{~min}$, the supernatant was incubated with guinea pig anti-Ptfla antibody-conjugated protein G Sepharose $4 \mathrm{~B}$ (Sigma) for $12 \mathrm{~h}$ at $4^{\circ} \mathrm{C}$. After being washed with lysis buffer, the proteins bound to Sepharose beads were solubilized with SDS sample buffer. Immunoprecipitants were immunoblotted with rabbit polyclonal anti-Myc antibody (A-14, Sigma) and visualized using peroxidase-conjugted secondary antibody followed by SuperSignal West Pico (Pierce).

\section{$R T-P C R$}

cDNA was prepared from 20 ng of total RNA from YFP fluorescence-activated cells sorted from E12.5 neural tubes from Ptf $1^{\text {Cre/+ }} /$ ROSA26YFP embryos using 16-mer oligo-dT primers and Sensiscript Reverse Transcriptase (Qiagen). One-twentieth of the cDNA solution was used for each PCR reaction. Samples not including reverse transcriptase were used to control for genomic DNA contamination. PCR was performed for 35 cycles of $30 \mathrm{sec}$ at $94^{\circ} \mathrm{C}, 30 \mathrm{sec}$ at $58^{\circ} \mathrm{C}$, and $30 \mathrm{sec}$ at $68^{\circ} \mathrm{C}$. The following primers were used to detect the expression of mRNA of PTF1 components and the control Gapdh: Ptfla-sense, 5'-TCATCC GTACAGCTAAAGTGTG-3'; Ptfla-antisense, 5'-TCTGTCA AAGGTGCTTCAGG-3'; Rbpj-sense, 5'-TGGCACTGTTCAA TCGCCTT-3'; Rbpi-antisense, 5'-AATCTTGGGAGTGCCAT GCCA-3'; Tcfe2a-sense, 5'-AGGTCCCACGCACGCGCACC 3'; Tcfe2a-antisense, 5'-CGCCTGCTGCAGGATGAGCA-3'; Tcf12-sense, 5'-CCATCCCCAAATTCTGACGAT-3'; Tcf12antisense, 5'-CTGGACATTGGCGGAAGACTT-3'; Tcf4sense, 5'-TGTACCCAATCACGACAGGA-3'; Tcf4-antisense, 5'-GCCAGCTCGTAGTATTTTGCC-3'; Gapdh-sense, 5'-GT GAGGCCGGTGCTGAGTAT-3'; Gapdh-antisense, 5'-TCAT GAGCCCTTCCACAATG-3'.

\section{Acknowledgments}

We are grateful to Dr. W. Pear for generating and sharing the DNMaml mouse strain. We thank Susan Hipkens for performing the recombinase-mediated cassette exchange procedure for

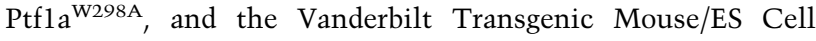
Shared Resource for performing the blastocyst microinjection experiments. We thank D. Anderson, T. Jessell, and T. Müller for antibodies; H. Edlund for the Ptfla-GST plasmid; and Drs. H. Lai and K. Zimmerman for critical reading of this manuscript. This work was funded by NIH R01 HD037932 to J.E.J., DK072473 to M.A.M., and DK61220 and DK55266 to R.J.M.

\section{References}

Barolo, S., Walker, R.G., Polyanovsky, A.D., Freschi, G., Keil, T., and Posakony, J.W. 2000. A notch-independent activity of suppressor of hairless is required for normal mechanoreceptor physiology. Cell 103: 957-969.

Beres, T., Masui, T., Swift, G.H., Shi, L., Henke, R.M., and MacDonald, R.J. 2006. PTF1 is an organ-specific and Notch-independent bHLH complex containing the mammalian Suppressor of Hairless (RBP-J) or its paralogue RBP-L. Mol. Cell. Biol. 26: 117-130.

Caspary, T. and Anderson, K.V. 2003. Patterning cell types in the dorsal spinal cord: What the mouse mutants say. Nat. Rev. Neurosci. 4: 289-297.

Cheng, L., Arata, A., Mizuguchi, R., Qian, Y., Karunaratne, A., Gray, P.A., Arata, S., Shirasawa, S., Bouchard, M., Luo, P., et al. 2004. Tlx3 and Tlx1 are post-mitotic selector genes determining glutamatergic over GABAergic cell fates. Nat. 
Neurosci. 7: 510-517.

Cheng, L., Abdel-Samad, O., Xu, Y., Mizuguchi, R., Luo, P., Shirasawa, S., Goulding, M., and Ma, Q. 2005. Lbx1 and Tlx3 are opposing switches in determining GABAergic versus glutamatergic transmitter phenotypes. Nat. Neurosci. 8: 15101515.

Cockell, M., Stevenson, B.J., Strubin, M., Hagenbuchle, O., and Wellauer, P.K. 1989. Identification of a cell-specific DNAbinding activity that interacts with a transcriptional activator of genes expressed in the acinar pancreas. Mol. Cell. Biol. 9: $2464-2476$.

de la Pompa, J.L., Wakeham, A., Correia, K.M., Samper, E., Brown, S., Aguilera, R.J., Nakano, T., Honjo, T., Mak, T.W., Rossant, J., et al. 1997. Conservation of the Notch signalling pathway in mammalian neurogenesis. Development 124: 1139-1148.

Engleka, K.A., Gitler, A.D., Zhang, M., Zhou, D.D., High, F.A., and Epstein, J.A. 2005. Insertion of Cre into the Pax3 locus creates a new allele of Splotch and identifies unexpected Pax3 derivatives. Dev. Biol. 280: 396-406.

Feng, Y.Q., Seibler, J., Alami, R., Eisen, A., Westerman, K.A., Leboulch, P., Fiering, S., and Bouhassira, E.E. 1999. Site-specific chromosomal integration in mammalian cells: Highly efficient CRE recombinase-mediated cassette exchange. $I$. Mol. Biol. 292: 779-785.

Fink, A.J., Englund, C., Daza, R.A., Pham, D., Lau, C., Nivison, M., Kowalczyk, T., and Hevner, R.F. 2006. Development of the deep cerebellar nuclei: Transcription factors and cell migration from the rhombic lip. J. Neurosci. 26: 3066-3076.

Fode, C., Ma, Q., Casarosa, S., Ang, S.L., Anderson, D.J., and Guillemot, F. 2000. A role for neural determination genes in specifying the dorsoventral identity of telencephalic neurons. Genes \& Dev. 14: 67-80.

Fujitani, Y., Fujitani, S., Luo, H., Qiu, F., Burlison, J., Long, Q., Kawaguchi, Y., Edlund, H., MacDonald, R.J., Furukawa, T., et al. 2006. Ptfla determines horizontal and amacrine cell fates during mouse retinal development. Development 133: 4439-4450.

Funahashi, J., Okafuji, T., Ohuchi, H., Noji, S., Tanaka, H., and Nakamura, H. 1999. Role of Pax-5 in the regulation of a mid-hindbrain organizer's activity. Dev. Growth Differ. 41: 59-72.

Furukawa, T., Mukherjee, S., Bao, Z.Z., Morrow, E.M., and Cepko, C.L. 2000. rax, Hes1, and notch1 promote the formation of Müller glia by postnatal retinal progenitor cells. Neuron 26: 383-394.

Gaiano, N., Nye, J.S., and Fishell, G. 2000. Radial glial identity is promoted by Notch1 signaling in the murine forebrain. Neuron 26: 395-404.

Glasgow, S.M., Henke, R.M., Macdonald, R.J., Wright, C.V., and Johnson, J.E. 2005. Ptfla determines GABAergic over glutamatergic neuronal cell fate in the spinal cord dorsal horn. Development 132: 5461-5469.

Gowan, K., Helms, A.W., Hunsaker, T.L., Collisson, T., Ebert, P.J., Odom, R., and Johnson, J.E. 2001. Crossinhibitory activities of Ngn1 and Math1 allow specification of distinct dorsal interneurons. Neuron 31: 219-232.

Gross, M.K., Dottori, M., and Goulding, M. 2002. Lbx1 specifies somatosensory association interneurons in the dorsal spinal cord. Neuron 34: 535-549.

Guimera, J., Weisenhorn, D.V., and Wurst, W. 2006. Megane/ Heslike is required for normal GABAergic differentiation in the mouse superior colliculus. Development 133: 3847-3857.

Helms, A.W. and Johnson, J.E. 1998. Progenitors of dorsal commissural interneurons are defined by MATH1 expression.
Development 125: 919-925.

Helms, A.W. and Johnson, J.E. 2003. Specification of dorsal spinal cord interneurons. Curr. Opin. Neurobiol. 13: 42-49.

Helms, A.W., Battiste, J., Henke, R.M., Nakada, Y., Simplicio, N., Guillemot, F., and Johnson, J.E. 2005. Sequential roles for Mash1 and Ngn2 in the generation of dorsal spinal cord interneurons. Development 132: 2709-2719.

Hitoshi, S., Alexson, T., Tropepe, V., Donoviel, D., Elia, A.J., Nye, J.S., Conlon, R.A., Mak, T.W., Bernstein, A., and van der Kooy, D. 2002. Notch pathway molecules are essential for the maintenance, but not the generation, of mammalian neural stem cells. Genes \& Dev. 16: 846-858.

Honjo, T. 1996. The shortest path from the surface to the nucleus: RBP-J $\kappa / \mathrm{Su}(\mathrm{H})$ transcription factor. Genes Cells $\mathbf{1}$ : $1-9$.

Hoshino, M., Nakamura, S., Mori, K., Kawauchi, T., Terao, M., Nishimura, Y., Fukuda, A., Fuse, T., Matsuo, N., Sone, M., et al. 2005. Ptfla, a bHLH transcriptional gene, defines GABAergic neuronal fates in cerebellum. Neuron 47: 201213.

Hoveyda, N., Shield, J.P., Garrett, C., Chong, W.K., Beardsall, K., Bentsi-Enchill, E., Mallya, H., and Thompson, M.H. 1999. Neonatal diabetes mellitus and cerebellar hypoplasia/agenesis: Report of a new recessive syndrome. J. Med. Genet. 36: 700-704.

Jarriault, S., Brou, C., Logeat, F., Schroeter, E.H., Kopan, R., and Israel, A. 1995. Signalling downstream of activated mammalian Notch. Nature 377: 355-358.

Joyner, A.L. and Zervas, M. 2006. Genetic inducible fate mapping in mouse: Establishing genetic lineages and defining genetic neuroanatomy in the nervous system. Dev. Dyn. 235: 2376-2385.

Kao, H.Y., Ordentlich, P., Koyano-Nakagawa, N., Tang, Z., Downes, M., Kintner, C.R., Evans, R.M., and Kadesch, T. 1998. A histone deacetylase corepressor complex regulates the Notch signal transduction pathway. Genes \& Dev. 12: 2269-2277.

Kawaguchi, Y., Cooper, B., Gannon, M., Ray, M., MacDonald, R.J., and Wright, C.V.E. 2002. The role of the transcriptional regulator Ptfla in converting intestinal to pancreatic progenitors. Nat. Genet. 32: 128-134.

Krapp, A., Knofler, M., Frutiger, S., Hughes, G.J., Hagen-buchle, O., and Wellauer, P.K. 1996. The p48 DNA-binding subunit of transcription factor PTF1 is a new exocrine pancreas-specific basic helix-loop-helix protein. EMBO J. 15: 4317-4329.

Krapp, A., Knofler, M., Ledermann, B., Burki, K., Berney, C., Zoerkler, N., Hagenbuchle, O., and Wellauer, P.K. 1998. The bHLH protein PTF1-p48 is essential for the formation of the exocrine and the correct spatial organization of the endocrine pancreas. Genes \& Dev. 12: 3752-3763.

Lee, E.C., Yu, D., Martinez de Velasco, J., Tessarollo, L., Swing, D.A., Court, D.L., Jenkins, N.A., and Copeland, N.G. 2001. A highly efficient Escherichia coli-based chromosome engineering system adapted for recombinogenic targeting and subcloning of BAC DNA. Genomics 73: 56-65.

Lo, L.-C., Johnson, J.E., Wuenschell, C.W., Saito, T., and Anderson, D.J. 1991. Mammalian achaete-scute homolog 1 is transiently expressed by spatially-restricted subsets of early neuroepithelial and neural crest cells. Genes \& Dev. 5: 15241537.

Long, Q., Shelton, K.D., Lindner, J., Jones, J.R., and Magnuson, M.A. 2004. Efficient DNA cassette exchange in mouse embryonic stem cells by staggered positive-negative selection. Genesis 39: 256-262.

Louvi, A. and Artavanis-Tsakonas, S. 2006. Notch signalling in vertebrate neural development. Nat. Rev. Neurosci. 7: 93-102. 
Massari, M.E. and Murre, C. 2000. Helix-loop-helix proteins: Regulators of transcription in eucaryotic organisms. Mol. Cell. Biol. 20: 429-440.

Masui, T., Long, Q., Beres, T.M., Magnuson, M.A., and MacDonald, R.J. 2007. Early pancreatic development requires the vertebrate Suppressor of Hairless (RBPJ) in the PTF1 bHLH complex. Genes \& Dev. 21: 2629-2643.

Matsunaga, E., Araki, I., and Nakamura, H. 2001. Role of Pax3/7 in the tectum regionalization. Development 128: $4069-4077$.

Megason, S.G. and McMahon, A.P. 2002. A mitogen gradient of dorsal midline Wnts organizes growth in the CNS. Development 129: 2087-2098.

Miyoshi, G., Bessho, Y., Yamada, S., and Kageyama, R. 2004. Identification of a novel basic helix-loop-helix gene, Heslike, and its role in GABAergic neurogenesis. J. Neurosci. 24: 3672-3682.

Mizuguchi, R., Kriks, S., Cordes, R., Gossler, A., Ma, Q., and Goulding, M. 2006. Ascl1 and Gsh1/2 control inhibitory and excitatory cell fate in spinal sensory interneurons. Nat. Neurosci. 9: 770-778.

Müller, T., Brohmann, H., Pierani, A., Heppenstall, P.A., Lewin, G.R., Jessell, T.M., and Birchmeier, C. 2002. The homeodomain factor Lbxl distinguishes two major programs of neuronal differentiation in the dorsal spinal cord. Neuron 34: 551-562.

Muramatsu, T., Mizutani, Y., Ohmori, Y., and Okumura, J. 1997. Comparison of three nonviral transfection methods for foreign gene expression in early chicken embryos in ovo. Biochem. Biophys. Res. Commun. 230: 376-380.

Nakada, Y., Hunsaker, T.L., Henke, R.M., and Johnson, J.E. 2004. Distinct domains within Mash1 and Math1 are required for function in neuronal differentiation versus celltype specification. Development 131: 1319-1330.

Nakatani, T., Minaki, Y., Kumai, M., and Ono, Y. 2007. Helt determines GABAergic over glutamatergic neuronal fate by repressing Ngn genes in the developing mesencephalon. Development 134: 2783-2793.

Nakhai, H., Sel, S., Favor, J., Mendoza-Torres, L., Paulsen, F., Duncker, G.I., and Schmid, R.M. 2007. Ptfla is essential for the differentiation of GABAergic and glycinergic amacrine cells and horizontal cells in the mouse retina. Development 134: 1151-1160.

Ohtsuka, T., Ishibashi, M., Gradwohl, G., Nakanishi, S., Guillemot, F., and Kageyama, R. 1999. Hes1 and Hes5 as notch effectors in mammalian neuronal differentiation. EMBO $I$. 18: 2196-2207.

Pascual, M., Abasolo, I., Mingorance-Le Meur, A., Martinez, A., Del Rio, J.A., Wright, C.V., Real, F.X., and Soriano, E. 2007. Cerebellar GABAergic progenitors adopt an external granule cell-like phenotype in the absence of Ptfla transcription factor expression. Proc. Nat1. Acad. Sci. 104: 5193-5198.

Rodriguez, C.I., Buchholz, F., Galloway, J., Sequerra, R., Kasper, J., Ayala, R., Stewart, A.F., and Dymecki, S.M. 2000. Highefficiency deleter mice show that FLPe is an alternative to Cre-loxP. Nat. Genet. 25: 139-140.

Rose, S.D., Swift, G.H., Peyton, M.J., Hammer, R.E., and MacDonald, R.J. 2001. The role of PTF1-P48 in pancreatic acinar gene expression. J. Biol. Chem. 276: 44018-44026.

Roux, E., Strubin, M., Hagenbuchle, O., and Wellauer, P.K. 1989. The cell-specific transcription factor PTF1 contains two different subunits that interact with the DNA. Genes \& Dev. 3: 1613-1624.

Schwenk, F., Baron, U., and Rajewsky, K. 1995. A cre-transgenic mouse strain for the ubiquitous deletion of loxP-flanked gene segments including deletion in germ cells. Nucleic Ac- ids Res. 23: 5080-5081.

Sellick, G.S., Barker, K.T., Stolte-Dijkstra, I., Fleischmann, C., Coleman, R.J., Garrett, C., Gloyn, A.L., Edghill, E.L., Hattersley, A.T., Wellauer, P.K., et al. 2004. Mutations in PTF1A cause pancreatic and cerebellar agenesis. Nat. Genet. 36: 1301-1305.

Soriano, P. 1999. Generalized lacZ expression with the ROSA26 Cre reporter strain. Nat. Genet. 21: 70-71.

Suemori, H., Kadodawa, Y., Goto, K., Araki, I., Kondoh, H., and Nakatsuji, N. 1990. A mouse embryonic stem cell line showing pluripotency of differentiation in early embryos and ubiquitous $\beta$-galactosidase expression. Cell Differ. Dev. 29: 181-186.

Tanigaki, K., Han, H., Yamamoto, N., Tashiro, K., Ikegawa, M., Kuroda, K., Suzuki, A., Nakano, T., and Honjo, T. 2002. Notch-RBP-J signaling is involved in cell fate determination of marginal zone B cells. Nat. Immunol. 3: 443-450.

Taniguchi, Y., Furukawa, T., Tun, T., Han, H., and Honjo, T. 1998. LIM protein KyoT2 negatively regulates transcription by association with the RBP-J DNA-binding protein. Mol. Cell. Biol. 18: 644-654.

Tsuchida, T., Ensini, M., Morton, S.B., Baldassare, M., Edlund, T., Jessell, T.M., and Pfaff, S.L. 1994. Topographic organization of embryonic motor neurons defined by expression of LIM homeobox genes. Cell 79: 957-970.

Tu, L., Fang, T.C., Artis, D., Shestova, O., Pross, S.E., Maillard, I., and Pear, W.S. 2005. Notch signaling is an important regulator of type 2 immunity. J. Exp. Med. 202: 1037-1042.

Wildner, H., Muller, T., Cho, S.H., Brohl, D., Cepko, C.L., Guillemot, F., and Birchmeier, C. 2006. dILA neurons in the dorsal spinal cord are the product of terminal and non-terminal asymmetric progenitor cell divisions, and require Mash1 for their development. Development 133: 2105-2113. 


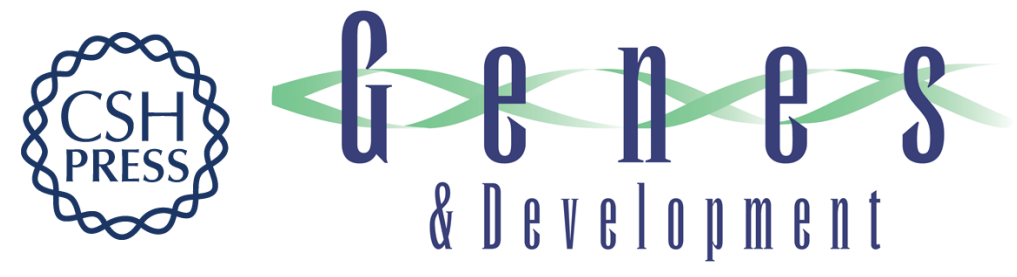

\section{A nonclassical bHLH-Rbpj transcription factor complex is required for specification of GABAergic neurons independent of Notch signaling}

Kei Hori, Justyna Cholewa-Waclaw, Yuji Nakada, et al.

Genes Dev. 2008, 22:

Access the most recent version at doi:10.1101/gad.1628008

Supplemental
Material http://genesdev.cshlp.org/content/suppl/2008/01/16/22.2.166.DC1

References This article cites 61 articles, 28 of which can be accessed free at:

http://genesdev.cshlp.org/content/22/2/166.full.html\#ref-list-1

License

Email Alerting Receive free email alerts when new articles cite this article - sign up in the box at the top

Service right corner of the article or click here.

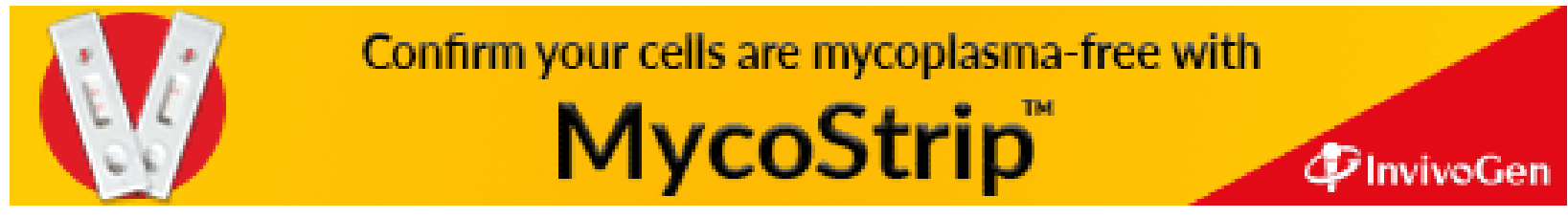

